\title{
Recent Progress in the Photovoltaic Manufacturing Technology Project (PVMaT)
}

C.E. Witt, L.O. Herwig, R.L. Mitchell, H. Thomas, R. Sellers, and D. Ruby

Prepared for the First World Conference on Photovoltaic Energy Conversion

December 5-9, 1994

Waikoloa, Hawaii

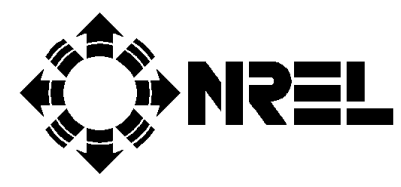

National Renewable Energy Laboratory 1617 Cole Boulevard

Golden, Colorado 80401-3393

A national laboratory of the U.S. Department of Energy Managed by Midwest Research Institute for the U.S. Department of Energy under contract No. DE-AC36-83CH10093

Prepared under Task No.PV550101

December 1994 


\section{NOTICE}

This report was prepared as an account of work sponsored by an agency of the United States government. Neither the United States government nor any agency thereof, nor any of their employees, makes any warranty, express or implied, or assumes any legal liability or responsibility for the accuracy, completeness, or usefulness of any information, apparatus, product, or process disclosed, or represents that its use would not infringe privately owned rights. Reference herein to any specific commercial product, process, or service by trade name, trademark, manufacturer, or otherwise does not necessarily constitute or imply its endorsement, recommendation, or favoring by the United States government or any agency thereof. The views and opinions of authors expressed herein do not necessarily state or reflect those of the United States government or any agency thereof.

Available to DOE and DOE contractors from:

Office of Scientific and Technical Information (OSTI)

P.O. Box 62

Oak Ridge, TN 37831

Prices available by calling (615) $576-8401$

Available to the public from:

National Technical Information Service (NTIS)

U.S. Department of Commerce

5285 Port Royal Road

Springfield, VA 22161

(703) $487-4650$ 


\title{
RECENT PROGRESS IN THE PHOTOVOLTAIC MANUFACTURING TECHNOLOGY PROJECT (PVMaT)
}

\author{
C. Edwin Witt, NREL; Lloyd O. Herwig, U.S. Department of Energy; \\ Richard L. Mitchell, NREL; Holly Thomas, NREL; \\ Rick Sellers, SEIA; Douglas S. Ruby, SNL
}

\author{
National Renewable Energy Laboratory \\ 1617 Cole Boulevard \\ Golden, Colorado 80401
}

\begin{abstract}
The Photovoltaic Manufacturing Technology (PVMaT) Project was initiated in 1990 to help the U.S. photovoltaic (PV) industry extend its world leadership role in manufacturing and commercially developing PV modules and systems. It is being conducted in several phases, staggered to support industry progress. The four most recently awarded subcontracts (Phase 2B) are now completing their first year of research. They include two subcontracts in CdTe, one on Spheral Solar ${ }^{\mathrm{TM}}$ Cells, and one on cast polysilicon. These subcontracts represent new technology additions to the PVMaT Project. Subcontracts initiated in earlier phases are nearing completion, and their progress is summarized. An additional phase of PVMaT, Phase $4 A$, is being initiated which will emphasize productdriven manufacturing research and development. The intention of Phase $4 \mathrm{~A}$ is to emphasize improvement and cost reduction in the manufacture of full-system PV products. The work areas may include, but not limited to, issues such as improvement of module manufacturing processes; system and system component packaging, integration, manufacturing, and assembly; product manufacturing flexibility; and balance-of-system development with the goal of product manufacturing improvements.
\end{abstract}

\section{INTRODUCTION}

The Photovoltaic Manufacturing Technology (PVMaT) Project was initiated in 1990 to help U.S. photovoltaic (PV) industry extend its world leadership role in PV manufacturing and the commercial development of PV modules and systems. As previously described $[1,2]$, the PVMaT Project is a government/industry research and development (R\&D) partnership between the U.S. federal government (through the U.S. Department of Energy [DOE]) and members of the U.S. PV industry. PVMaT is designed to accomplish this by helping the U.S. PV industry improve manufacturing processes, accelerate manufacturing cost reductions for PV modules, improve commercial product performance, and lay the groundwork for a substantial scale-up in the capacity of U.S.-based PV manufacturing plants.

The PVMaT Project is being carried out in four separate phases, designed to address separate $R \& D$ requirements. These phases are Phase 1, Phase 2A, Phase 2B, Phase $3 A$, and Phase $4 A$. Each phase is aimed at achieving the PVMaT goals and is coordinated to support the specific needs of the PV industry as it makes progress toward module cost reduction and production capacity scale-up. Table 1 identifies the major PVMaT (Phases 2 and 3) awards to date. Phase 1 of this project was a problemidentification phase of about 3 months duration. During Phase 1, the status and needs of the U.S. PV manufacturing industry were identified, and a Phase 2 procurement responsive to the industry's needs was developed. The Phase 1 subcontracts were completed in 1991.

Phase 2 addresses process-specific module manufacturing problems of individual manufacturers. The first solicitation under this phase (Phase 2A) was open only to organizations that received awards under the Phase 1 solicitation. Seven 3-year subcontracts were implemented in early 1992 . The Phase $2 A$ subcontracts through the National Renewable Energy Laboratory (NREL) were cost-shared between the U.S. government and the U.S. PV industry participants. A description of subcontracted R\&D activities and technical accomplishments under Phase 2A are presented below. The next PVMaT Phase 2 effort (Phase 2B) was a solicitation open to all U.S. PV industrial firms. This allowed organizations not ready for the earlier Phase 2A procurement cycle, or which were not participants in Phase 1 , to have a chance to "ramp on" and participate in this process-specific solution phase of the PVMaT Project. Four 3-year subcontracts were awarded under this solicitation in late 1993. 


\section{Table 1. PVMaT Subcontract Awards by Phase}

Subcontractor

PHASE 2A - Process Specific Research

AstroPower, Inc.

Energy Conversion

Devices

Entech, Inc.

Mobil Solar Energy Corp.

Siemens Solar Industries

Solarex Corp.

Utility Power Group Silicon-Film Photovoltaic Manufacturing
Technology

Continuous Roll-to-Roll Amorphous Silicon Photovoltaic Manufacturing Technology

Photovoltaic Manufacturing Technology Improvements for Entech's Concentrator Module

Thin Edge-Defined, Film-Fed, Growth of Octagons

Photovoltaic $\mathrm{Cz}$ Silicon Manufacturing Technology Improvements

Large-Area, Multi-Junction a-Si Alloy Production Scale-Up Project

Amorphous Silicon Photovoltaic Manufacturing Technology
Principal Investigator
Subcontract Total Value $t$.
Sandi Collins

Robert Hall

Masatsugu lzu

Mark O'Neill

Juris Kalejs

Terry Jester

Robert Oswald

Michael Stern

Gil Duran
$\$ 10.8 \mathrm{M}$

$\$ 7.1 \mathrm{M}$

$\$ 3.2 \mathrm{M}$

$\$ 9.1 \mathrm{M}$

$\$ 10.5 \mathrm{M}$

$\$ 10.0 \mathrm{M}$

$\$ 4.9 \mathrm{M}$

PHASE 2B - Process Specific Research

Golden Photon, Inc.

Solar Cells, Inc.

Solarex Corp.

Texas Instruments
Commercial Scale-Up of Advanced Thin-Film Photovoltaic Technologies

High-Throughput Manufacturing of Thin-Film CdTe Photovoltaic Modules

Cast Polycrystalline Silicon Photovoltaic Cell and Module Manufacturing Technology Improvements

Photovoltaic Manufacturing Technology Phase 2B - Spheral Solar Technology
Steve Johnson

$\$ 9.8 \mathrm{M}$

Dan Sandwisch

$\$ 7.4 \mathrm{M}$

John Wohlgemath

Jim Skelly

Rusty Schmit

PHASE 3A - Teamed Research

Spire Corp.

Springborn Laboratories
Automated Solar Cell Assembly Teamed Process Research

Photovoltaic Manufacturing Technology
Mike Nowlan

$\$ 1.4 \mathrm{M}$

Bill Holley 
Phase 3 of the PVMaT Project addresses R\&D, through a teamed research approach, problems that are common to the PV industry as a whole. Two subcontracts were awarded in January of 1993. They focus on module-related R\&D problems as listed in Table 1 above.

An additional phase of PVMaT, Phase 4A, is in progress. This phase will emphasize product-driven manufacturing R\&D. The intention of the Phase 4A procurement is to emphasize improvement and cost reduction in the manufacture of full-system PV products. A further description, by phase, of the R\&D activities addressed is detailed below.

\section{PHASE 2A}

The PVMaT Phase 2A subcontracts awarded in 1992 are completing their third and final year of research. The progress and accomplishments of each are discussed below.

\section{AstroPower, Inc.}

AstroPower, Inc., of Newark, Delaware, has focused its PVMaT efforts on enhancing its Silicon-Film ${ }^{\mathrm{TM}} \mathrm{PV}$ manufacturing production capabilities, optimizing its solar cell processing, and improving the polycrystalline SiliconFilm $^{\mathrm{TM}}$ module assembly portion of its manufacturing line. AstroPower's goals under the PVMaT Project are to (1) design, construct, and demonstrate a production machine that generates sheets of Silicon-Film ${ }^{\mathrm{TM}}$ at a wafer production rate equivalent to $3 \mathrm{MW} / \mathrm{yr}$; (2) develop a low-cost fabrication process for $3.15-W$ solar cells that are $15 \mathrm{~cm}$ by $15 \mathrm{~cm}$; and (3) develop a large-area module production line that produces $113-\mathrm{Wp}, 0.9-\mathrm{m}^{2}$ modules and $170 \mathrm{Wp}, 1.4-\mathrm{m}^{2}$ modules.

AstroPower's accomplishments after 2.5 years of this subcontract include; fabricating the first $15-\mathrm{cm} \times 45-\mathrm{cm}$ Silicon-Film ${ }^{\mathrm{TM}}$ cell (the largest solar cell ever produced); a reduction in Silicon-Film ${ }^{\mathrm{TM}}$ wafer cost by $53 \%$ and module fabrication costs by $42 \%$; demonstrating an $1000 \%$ increase in Silicon-Film ${ }^{\mathrm{TM}}$ wafer production capacity at 4.4-MW/yr ( $47 \%$ higher than its third-year project goals); an increase in 238-cm $\mathrm{cm}^{2}$ (AP-225) cell fabrication capacity; demonstration of an NREL-verified $11.8 \%$ efficiency for the Silicon-Film ${ }^{\mathrm{TM}}$ AP225 cell at $2.82 \mathrm{Wp}$, and a 93-Wp module assembled into $0.9-\mathrm{m}^{2}$ with 36 of these AP-225 Silicon-Film ${ }^{\mathrm{TM}}$ cells.

\section{Energy Conversion Devices, Inc.}

Energy Conversion Devices (ECD), of Troy, Michigan, has directed its research efforts at the development of the continuous roll-to-roll amorphous silicon (a-Si) PV manufacturing technology. ECD's overall goals under this subcontract are to (1) support production of $0.3-\mathrm{m} \times 1.2-\mathrm{m}$ (1-ft $x$ 4-ft) triple-junction a-Si:Ge alloy modules with $10.2 \%$ stable efficiency; (2) enhance the effective production throughput by developing advanced serpentine deposition techniques; and (3) reduce material and labor costs. Successful implementation of this project will allow ECD to work toward an ultimate goal of building a 100-MW/yr roll-toroll, automated a-Si module manufacturing facility. At this anticipated production capacity, ECD expects to reduce the cost of PV modules to less than $\$ 1.00 \mathrm{~N}_{\mathrm{p}}$.

ECD's accomplishments after the second phase of this subcontract include demonstrating production of triplejunction solar cells with $11.1 \%$ initial conversion efficiency; demonstrating $8 \%$ stabilized efficiency on a $0.37-\mathrm{m}^{2}, 31-$ $\mathrm{W}_{\max }$ triple-junction a-Si module; demonstrating full production runs $(762 \mathrm{~m}$ ) with $99.7 \%$ subcell yield and high uniformity; demonstrated material cost reductions of $77 \%$ for germane, $58 \%$ for disilane, and $30 \%$ for module assembly; completing improvements to the ECD a-Si:Ge alloy deposition system; establishing the first roll-to-roll a-Si:Ge production line facility; producing a triple-junction, small-area cell utilizing a new serpentine deposition technology for the intrinsic a-Si layer, resulting in an initial conversion efficiency of $9.5 \%$ with improved gas utilization of $20 \%-30 \%$; the development of an improved textured $\mathrm{Ag} / \mathrm{ZnO}$ backreflector system demonstrating a $26 \%$ gain in short-circuit current over the previous textured Al back-reflector system; the development of a new grid/bus-bar design utilizing thin wire grids that improve relative module efficiency by $3 \%-4 \%$ and reduce grid/bus-bar material cost by approximately $50 \%$; and reducing material costs by $56 \%$ through cumulative improvements.

Entech, Inc.

Entech, Inc., of Dallas-Fort-Worth, Texas, has directed it's research under its PVMaT subcontract at PV manufacturing technology improvements for Entech's $21 \mathrm{X}$ linear concentrator module. The specific Entech goals under this project are to (1) enhance its concentrator module quality; (2) increase the Entech concentrator module performance; (3) improve product durability; (4) expand the Entech manufacturing capacity to $10-\mathrm{MW} / \mathrm{yr} ;$ (5) address environmental, safety, and health issues; (6) reduce Entech module manufacturing costs; and (7) increase Entech manufacturing line automation. Successful completion of this research is expected to result in a linear concentrator module manufacturing plant with the capability of producing PV modules at a rate of $10 \mathrm{MW} / \mathrm{yr}$.

Entech's accomplishments after 2.5 years of this subcontract include working with $3 \mathrm{M}$ to develop an improved prismatic solar cell lens cover tape, reducing both material and labor costs by $90 \%$; identifying four separate sources of process-compatible advanced cells, three of which provide 
$19 \%$-efficient cells; working with $3 \mathrm{M}$ to develop a continuous, prelaminated, rolled Fresnel lens which resulted in both a $20 \%$ materials cost reduction and the elimination of solvent use in the Entech process; developing ribbon solder techniques resulting in an $80 \%$ reduction in labor and materials costs; working with Columbia Aluminum to develop the world's largest extruded heat sink; developing a semiautomated work station to align and attach prism covers to solar cells; developing new dry-film processes for attaching cell strings to the heat sink and encapsulating the cell assembly; establishing a team capable of producing lenses, heat sinks, and cells at rates well above $10 \mathrm{MW} / \mathrm{yr}$, with capability for a quick scale-up to $100 \mathrm{MW} / \mathrm{yr}$; and developing a new fourth-generation module with a power output of greater that $430 \mathrm{~W}$.

\section{Mobil Solar Energy Corp.}

Mobil Solar Energy Corp. (MSEC), of Billerica, Massachusetts (whose technology has recently been purchased by, and is being pursued by, ASE Americas, Inc.), directed its research under Phase $2 A$ toward thin Edge-Defined Film-Fed Growth (EFG) of octagons. MSEC research under this phase had specific goals that included (1) producing $250-\mu \mathrm{m}$-thick wafers and solar cells using EFG technology; (2) increasing production throughput at the laser cutting station by a factor of two; (3) developing a new encapsulant to protect the module's PV cells against corrosion; and (4) developing a module that uses glass as the back covering for greater protection against cuts, tears, and penetrations.

MSEC's subcontracted activities under PVMaT were reduced to 2 years at the request of MSEC during its pending acquisition. During this 2-year period, its accomplishments included producing 250- $\mu$ m-thick wafers resulting in $13.8 \%$-efficient solar cells from production-line materials; eliminating most wet-chemistry processing from its production line; developing a radically new non- ethylene vinyl acetate (EVA) material that is inert and stable at all module operating temperatures and protects its module against corrosion and moisture egression; developing a glass lamination for both the front and back of the module; completing specifications for a factory prototype EFG octagon crystal-growth furnace designed for the production of 300- $\mu \mathrm{m}$-thick Si wafers; demonstrating the feasibility of laser cutting Si wafers near the low-damage threshold with a 585-nm high-power dye laser; developing and deploying a laser cutting station that increases production line throughput by a factor of two; and testing and analyzing potential Si EFG growth improvements that resulted in an estimated module cost reduction of $15 \%$.

\section{Siemens Solar Industries}

Siemens Solar Industries (SSI), of Camarillo, California, is investigating improvements to its Czochralski $(\mathrm{Cz})$ Silicon PV manufacturing technology. Its goals for this research include (1) improving $\mathrm{Cz}$ Si-ingot quality; (2) increasing the materials use efficiency for crystalline $\mathrm{Si}$ (c-Si) wafer sawing; (3) investigating improvements in device processing; (4) investigating the introduction of automation to a significant portion of its C-Si module manufacturing lines; (5) and reducing the amount of hazardous waste generated. The successful completion of this project was expected to result in a decrease in SSI's c-Si module costs of more than half while doubling its U.S. manufacturing capability.

SSI's accomplishments after 2.5 years under this subcontract include an increase in wire-saw production capacity by $>30 \%$ due to reduced kerf loss and thinner wafer processing; a $3 \%$ increase in crystal growth yields as a result of studies on polysilicon feedstock; elimination of Freon use, and incorporation of a no-clean solder paste in SSl's module production by April 1993; incorporation of graphite design changes into the SSI crystal growers, which has resulted in a $30 \%$ savings of $\$ 300 \mathrm{~K} / \mathrm{yr}$; increased capacity of crystal growers by $20 \%$; a new lower-cost junction box; increased average cell yield by $4 \%$ since 1992 ; and concentrating of plant waste streams, reducing waste volume by $10 \%$ and waste costs by $20 \%$.

\section{Solarex Corporation}

Solarex Corporation, of Newtown, Pennsylvania, is focusing on the large-area, multi-junction, a-Si alloy production scaleup. The goals of this effort include (1) improving the deposition and quality of its transparent front contact; (2) optimizing its laser patterning process; (3) scaling up the semiconductor deposition process; (4) improving the back contact deposition; and (5) scaling up and improving the encapsulation and testing of its a-Si:H modules. Successful completion of this 3-year project will result in Solarex producing a-Si:H modules of $\sim 0.37 \mathrm{~m}^{2}\left(4 \mathrm{ft}^{2}\right), 10 \%$ stabilized efficiency, $50 \mathrm{~W}$, and a total overall module yield of $z 75 \%$. At a proposed production capacity of $10 \mathrm{MW} / \mathrm{yr}$, this would result in a potential module cost reduction from the present price of $\$ 11.05 \mathrm{~W}_{\mathrm{p}}$ to $\$ 1.14 \mathrm{~N}_{\mathrm{p}}$.

Solarex's accomplishments after 2.5 years of this subcontract include improvements in the manufacturing process and a reduction in manufacturing costs through the development of front-contact deposition equipment, which uses a simpler and more cost-effective chemistry for frontcontact deposition. Other progress includes increased laser processing throughputs by factors of 1.5 to 7.5 ; a reduction of area losses caused by laser interconnects on large-area modules by $50 \%$; a demonstration of the Solarex a-Si deposition equipment capable of film thickness uniformity of 
$\pm 3 \%$ over an area of $0.74 \mathrm{~m}^{2}\left(8 \mathrm{ft}^{2}\right) ;$ a $40 \%$ increase in the rate of use for the raw material in the a-Si deposition process; and a $70 \%$ decrease in the raw material cost for rear contact deposition. One key result during the last year was the development of a new $0.37-\mathrm{m}^{2}$ monolithic a-Si multijunction module product with an initial conversion efficiency of $8.9 \%$.

\section{Utility Power Group}

Utility Power Group (UPG), of Chatsworth, California, and its major lower-tier subcontractor, Advanced Photovoltaic Systems (APS), of Princeton, New Jersey, have focused their research on a-Si PV manufacturing technology. UPG's goals under the PVMaT Project are to: (1) significantly advance its PV manufacturing technologies; (2) reduce module production costs; (3) increase average module performance; and (4) increase the production capacity of UPG's existing manufacturing facility. After identifying two specific process steps with the greatest potential for cost reduction in PVMaT Phase 1, UPG chose to concentrate its research efforts on two areas: encapsulation, with consideration given to approaches that do not require a second glass layer; and, automation of electrical termination.

The accomplishments by UPG after 2.5 years of this subcontract include: eliminating the back glass and developing a new scratch-resistance silicone back encapsulant that is impregnated with $100-\mu \mathrm{m}$ glass spheres, reducing encapsulation costs by $72 \%$; developing an advanced electrical termination system that takes advantage of the enhanced mechanical characteristics of the new encapsulant, resulting in a reduction in cost of more than $81 \%$; eliminating 30 steps from the Powerglass PV module termination and encapsulation manufacturing processes; increasing the average Powerglass module power rating; increasing the level of automation associated with the encapsulation and termination processes; completing Powerglass module qualification testing for candidate encapsulation materials; increasing the total power rated capacity of UPG's manufacturing facility by almost a factor of 5; and increasing throughput on the production line and decreasing overall Powerglass module production costs by $28 \%$.

\section{Advanced Photovoltaic Systems}

The goals of APS, as the major lower-tier subcontractor to UPG, are to greatly improve its PV manufacturing technology, primarily by improving process control, increasing automation of the manufacturing line, and improving the quality of its product.
After 2.5 years of work as a lower-tier subcontractor under the UPG/NREL subcontract, APS's accomplishments include the completion of the installed equipment automation in the new Eureka production factory; development of a new procedure for wire connection from the PV films, which significantly cut manufacturing costs through a $200 \%$ reduction in processing time; achievement of a manufacturing capacity increase by reducing EVA curing time by $64 \%$; an improvement in Si deposition uniformity to less than $\pm 10 \%$ over the more than $1.2-\mathrm{m}^{2}(13-$ $\mathrm{ft}^{2}$ ) of module area, contributing to an increased module power output of $10 \%$ to $15 \%$; designing full-scale Eureka modules, including enhancements developed under the PVMaT Project; and introduction of two new Eureka module products (a $25-\mathrm{W}$ and a $50-\mathrm{W}$ product for $12-\mathrm{V}$ applications).

\section{PHASE 2B}

Under Phase 2B, the most recently subcontracted phase of the PVMaT Project, NREL awarded four 3-year subcontracts in late 1993. These awards included two in CdTe module manufacturing, one on the manufacture of Spheral Solar ${ }^{\mathrm{TM}}$ cells and modules, and one on cast polysilicon wafers, cells, and module manufacturing. These subcontracts (listed in Table 1, with principle investigators and total funding level) represent new technological additions to the PVMaT Project, and are cost-shared at $58 \%$ by the subcontractors. This is a noticeable increase from the $42 \%$ cost-sharing by subcontractors under Phase $2 \mathrm{~A}$, as shown in Fig. 1.

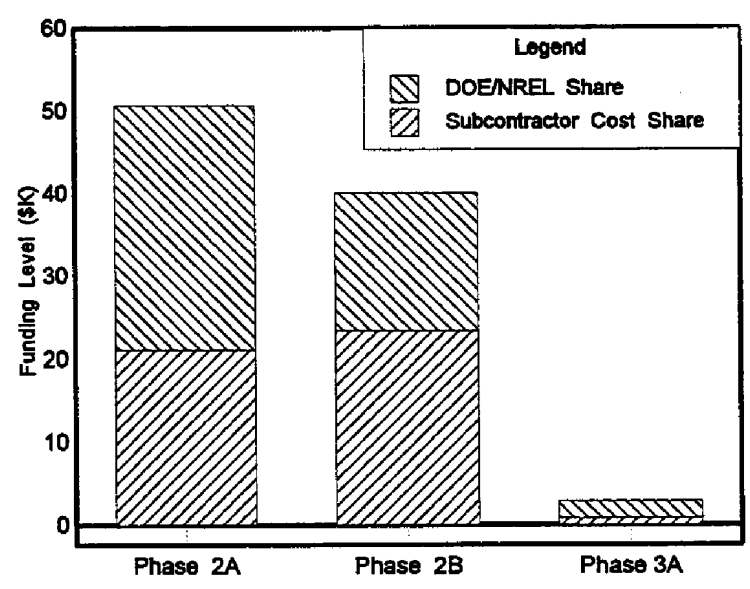

Fig. 1 PVMaT Partner\$hip Cost Share 


\section{Golden Photon, Inc.}

Golden Photon, Inc., of Golden, Colorado, is concentrating its activities on the commercial scale-up of advanced thinfilm CdS/CdTe PV modules produced using spray deposition. The goals set by Golden Photon for this subcontract include the development and implementation of (1) improved production processes and subsequent equipment designs that allow incremental scale-up to a 2MW/yr manufacturing capacity; (2) an employee exposure monitoring plan that will ensure employee safety from $\mathrm{Cd}$ exposure; and (3) environmental, safety, and health (ES\&H) programs that meet the requirements of all local, state, and national authorities. At the completion of the subcontract, these goals are expected to result in a 2-MW/yr CdTe module manufacturing line capable of production costs of about \$1.50-2.00 Wp.

Golden Photon's major accomplishment during the first year of this subcontract was the completion of its design for installation and start-up of a 2-MW/yr CdTe module manufacturing line, and its initiation of a "prove-in" phase of operation.

\section{Solar Cells, Inc.}

Solar Cells, Inc. $(\mathrm{SCl})$, of Toledo, Ohio, has directed its research at developing high-throughput manufacturing of thin-film CdTe PV modules. The goals of $\mathrm{SCl}$ under the PVMaT Project are to (1) advance its PV manufacturing technologies, (2) reduce module production costs, (3) increase module performance, and (4) provide the groundwork for $\mathrm{SCl}$ to expand its commercial production capacities. $\mathrm{SCl}$ plans to meet these objectives by designing, and debugging a 20-MW/yr, automated, continuous PV manufacturing line that produces $60-\mathrm{cm} \times 120-\mathrm{cm} \mathrm{CdTe}$ modules.

SCl's accomplishments after the first phase of this subcontract include completing improvements in raw material supply, glass conveyance, pressure control, and temperature control that have increased the $\mathrm{SCl}$ pilot system capacity by a factor of 100 ; designing a highthroughput deposition system for the a 20-MW line; initiating interim qualification testing of $\mathrm{SCl} 60-\mathrm{cm} \times 120-\mathrm{cm} \mathrm{CdTe}$ modules; increasing average module efficiencies by more than $15 \%$ (from $6.3 \%$ to $7.4 \%$ ); and implementing an ES\&H program for semiannual testing and monitoring of personnel exposure to $\mathrm{Cd}$.

\section{Solarex Corporation (Crystalline Silicon Division)}

Solarex Corporation, of Rockville, Maryland, has focused its research under this subcontract on advancing its cast-ingot polycrystalline Si PV module manufacturing technology. Solarex's goals under PVMaT Phase 2B are to (1) increase automation in module assembly and handling of larger wafers; (2) improve the module manufacturing throughput, yield, and process control; (3) reduce PV module production labor and production costs to less than $\$ 1.20 \mathrm{~W}$; (4) achieve an increase in solar cell performance from $12.8 \%$ to $15 \%$; (5) increase wafer production by using wire saws to reduce center-to-center cut distances from $600 \mu \mathrm{m}$ to $400 \mu \mathrm{m}$; (6) develop larger wafers through increased ingot casting sizes; and (7) expand commercial module manufacturing capacity by a factor of three.

Solarex's accomplishments after the first phase of this subcontract include implementing design modifications to one casting station which resulted in a $73 \%$ increase in production capacity and initiating some of the modifications to the remaining stations, increasing their production capacity by $20 \%$ each; the development of a process for casting larger ingots with a $15-\mathrm{cm} \times 15-\mathrm{cm}$ cross-section, and its transfer onto the manufacturing line to replace the previous bricks with a 11.4- $\mathrm{cm} \times 11.4-\mathrm{cm}$ cross-section; the integration of a new wire saw for the cutting cast polysilicon bricks; and the demonstration of an eight-brick-at-a-time wire-saw cutting run, which resulted in 2400 wafers in $8 \mathrm{hr}$.

Texas Instruments, Inc.

Texas Instruments, Inc. (TI), of Dallas, Texas, is directing its subcontract activities under PVMaT toward research on Spheral Solar ${ }^{\text {TM }}$ Si PV technology. Tl's goals under this subcontract are to (1) optimize existing processes; (2) investigate alternative approaches for reducing material waste, material handling (labor) costs, and cycle times of its Spheral Solar ${ }^{\mathrm{TM}}$ technology in order to demonstrate a module manufacturing process with costs of $\$ 2.00 \mathrm{~N}$; (3) increase manufacturing yield while reducing cost and improving logistics through sphere fabrication processes; (4) improve cell yields through optimization of bonding pressures, temperatures, and foil configuration parameters; and (5) increase Spheral Solar ${ }^{\mathrm{TM}}$ cell efficiencies from $8.5 \%$ to greater than $11 \%$.

Tl's accomplishments after the first phase of this subcontract include developing equipment capable of multi-megawatt production rates for the highest-risk processes; identifying a new proprietary furnace design to more effectively handle initial melt operations while increasing throughput and reducing capital costs; improving the front bond process, resulting in a $>65 \%$ increase in the yield on $>7.0 \%$-efficient unencapsulated cells; demonstrating cell yields as high as $90 \%$ on the pilot production line; investigating surface passivation using forming gas, resulting in an initial $1.8 \%$ increase in $V_{o c}$ and a $2.9 \%$ increase in the $J_{s c}$ for $10-\mathrm{cm}^{2}$ cells; and demonstrating an $8.3 \%$-efficient, $4000-\mathrm{cm}^{2}$ module utilizing a nonconventional encapsulant. 


\section{PHASE 3A}

The PVMaT Phase $3 A$ subcontracts both began in early January, 1993. They have focused on module-related R\&D problems that are common to several PV manufacturing groups.

\section{Spire Corp.}

Spire Corp., of Bedford, Massachusetts, has focused its research on automated solar cell assembly. Spire's overall goal under the PVMaT Project is to reduce PV costs by developing high-throughput (5-MW/yr), automated processes for interconnecting thin $(200-\mu \mathrm{m})$ Si solar cells. Significantly more $200-\mu \mathrm{m}$ wafers can be produced from a $\mathrm{Si}$ ingot than conventional $350-\mu \mathrm{m}$ to $400-\mu \mathrm{m}$ wafers, thus reducing cell cost. However, an unacceptably high breakage rate in processing normally makes such thin cells impractical. In this project, Spire has attempted to achieve high yields with these fragile cells by developing processes that reduce mechanical and thermal stresses and increase the use of automation and higher process throughput. At the completion of this subcontract, an automated processing system for cell tabbing is expected to be available as a commercial product to PV manufacturers.

Spire's accomplishments include the development of the prototype, fully automated Spi-Assembler ${ }^{T M} \mathbf{5 0 0 0}$ solar cell assembly system for processing standard and thin solar cells with cell-testing capabilities. They have developed low stress processes for loading, aligning, and soldering cells of different thicknesses. They have also conducted demonstration tests with the Spi-Assembler ${ }^{\text {TM }} 5000$ in cooperation with SSI, AstroPower, Solec, and others, using company-specific cells.

\section{Springborn Materials Science Corp.}

Springbom Materials Science Corp., of Enfield, Connecticut, has focused its research on understanding the degradation of EVA-based encapsulants in PV modules. Springborn's goals under the PVMaT Project are to (1) pursue the advanced development of a PV module encapsulation sheet, (2) reformulate the EVA-based elastomer, and (3) formulate alternative elastomer-based encapsulants that will more effectively resist degradation when exposed to high temperature and ultraviolet (UV) insolation in the field. Yellowing or browning of some EVA-based encapsulants has occurred at a number of installations woridwide, where both temperature and UV radiation are comparatively high.

Springborn's accomplishments after the first phase of this subcontract include establishing a baseline of information through a complete literature search and survey of case histories of EVA-based encapsulants in PV devices; completing accelerated testing on samples of various combinations of glass and encapsulants (e.g., EVA, Tedlar, etc.); and discovering that glass supplied recently (last several years) by two particular suppliers transmits significantly less radiation in the UV-B region than glass during the 1980s.

\section{PHASE 4A}

An additional phase of the PVMaT Project (Phase 4A) is now being initiated. This phase will emphasize productdriven manufacturing R\&D. The intention of Phase $4 A$ is to emphasize improvement and cost reduction in the manufacture of full-system PV products. The work areas may include, but will not be limited to, issues such as improvement of module manufacturing processes; system and system component packaging, integration, manufacturing, and assembly; product manufacturing flexibility; and balance-of-system development with the goal of product manufacturing improvements. The announcement for this solicitation was released in April 1994. Proposals in response to the Phase 4A solicitation were received in October 1994, and are currently in the evaluation stage with awards planned for mid-1995.

\section{PROGRESS IN COST REDUCTION AND CAPACITY INCREASES}

It is important to put the technical progress that the U.S. PV industry is making into perspective. Based on the improvements in manufacturing processes, reductions in manufacturing costs, introduction of new products, and improvements in product performance, it would be expected that the U.S. PV industry would exhibit both a scale-up of its U.S.-based PV manufacturing capacity and a reduction in its production costs. This has indeed been the case.

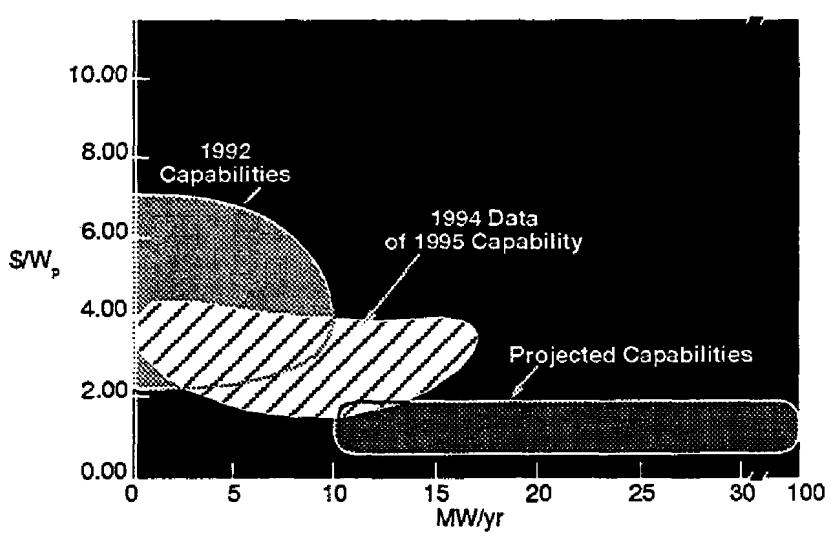

Fig. 2. PVMaT Phase 2A Initial Manufacturing Cost/Capacity Goals 
At the beginning of Phase 2A subcontracted research in the PVMaT Project, information was collected to establish the status of both the current and projected capacities and module costs for the eight subcontractors (APS was included as a lower-tier to UPG). These data, shown in Fig. 2, represented both the diverse status of a still-maturing industry and the optimistic speculation of its members regarding the effects that the PVMaT Project would have after PVMaT efforts were allowed to take effect. Additional information was collected as these subcontractors neared the completion of their individual subcontracts in late 1994. This recent data, shown in both Figs. 2 and 3, represents an update of the previous projections regarding these subcontracted efforts. Data projected in these figures are based on each manufacturer's maximum production capacity during a given year, assuming they were to operate 24-hr/d and 365-d/yr. Module cost estimates were then based on these manufacturing levels and included only those costs directly associated with the manufacturing of the modules (not marketing, administration, sales, etc.). It should be noted that data associated with any particular point in time, represent a potential capability. Actual manufacturing production levels may be less (and concomitant costs lower) due to other considerations such as market conditions, available labor, etc.

The data for establishing the 1995 module manufacturing costs have a relatively high degree of accuracy, since capital equipment for 1995 plant installations is generally already in place or on order. This lends significant credibility

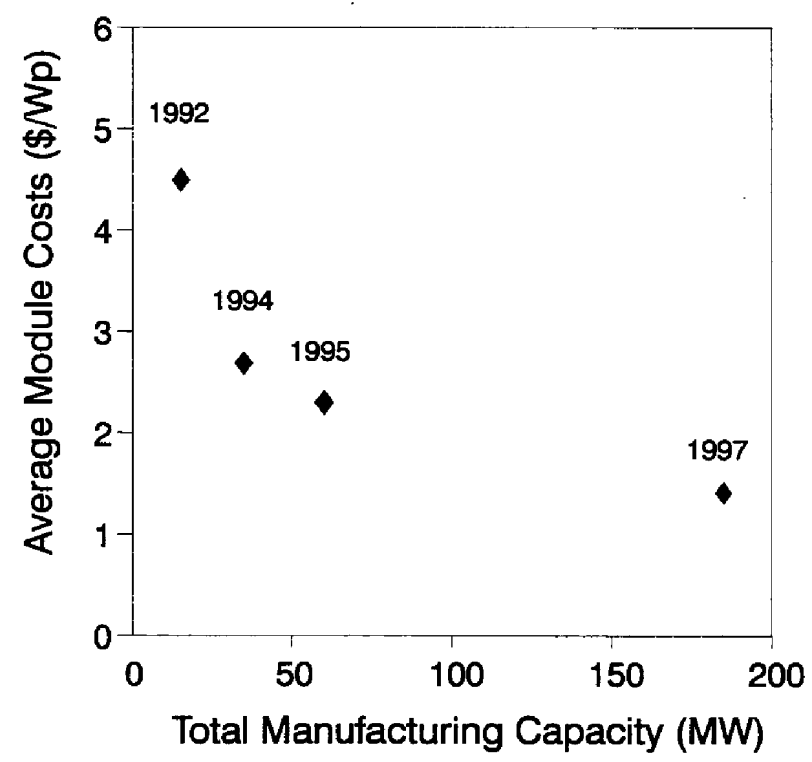

Fig. 3. PVMaT Phase 2A Current Manufacturing Cost/Capacity Levels to the trend represented in Fig. 3 for these eight Phase 2A subcontractors. When compared to the 1992 "Current Capabilities" and the "Projected Capabilities" in Fig. 2, the Phase 2A subcontractors appear to be on track to achieving their original goals.

In conjunction with the 1994 collection of Cost/Capacity data for the Phase 2A participants, an initial inquiry of the four PVMaT Phase 2B participants was conducted. The result of this data collection is presented in Fig. 4. The same diverse initial status and optimistic speculation regarding their future after their PVMaT supported research is represented. However, these participants had a higher ratio of "new technology manufacturers" involved in their group, as can be seen by the size and spread in initial module costs.

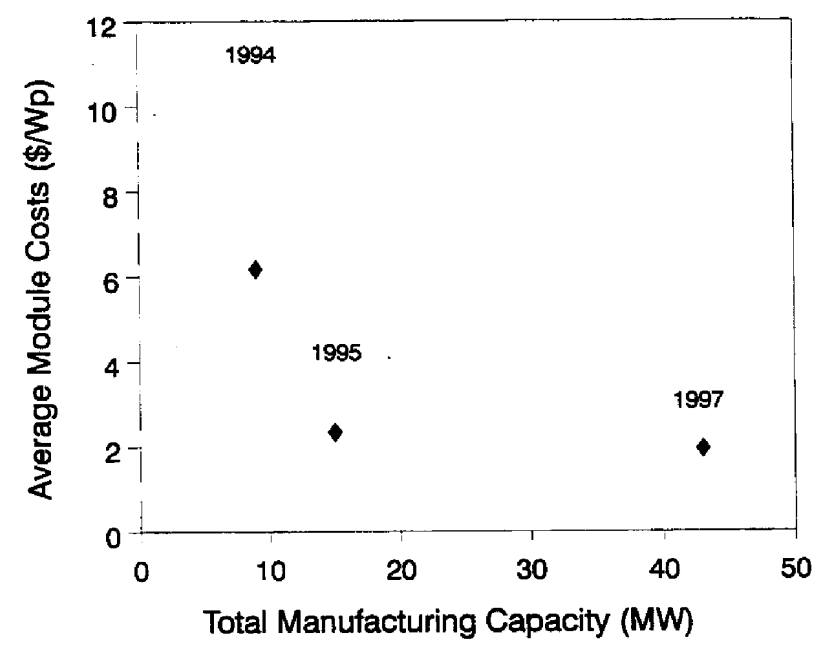

Fig. 4. PVMaT Phase 2B Current Manufacturing Cost/Capacity Levels

It is apparent, from Figs. 2-4, that the U.S. PV industry involved in the PVMaT Project has made significant progress toward reducing manufacturing costs and increasing PV module manufacturing capacity. It has also indicated in both its future Cost/Capacity date and its technical projections that its optimism for continuing these improvements is high.

\section{U.S. COMPETITIVENESS}

An indication of an industry's strength is the relative market share. Figure 5 [3] shows the U.S. market share on a world basis suffered a significant decline in the early $1980 \mathrm{~s}$. Although the U.S. PV market share began declining in 1982 , the marked decline of production in 1985 clearly reflects the end of energy tax credits in the United States. Since that 
time, the U.S. production has hovered between $30 \%$ and $36 \%$ of the world total. It is promising, however, that the U.S. market share strengthened in 1993, achieving $35 \%$ of the world shipments. We believe an element of this strengthening position is the result of a new generation of PV modules with improved performance and durability, and there modules have been developed with the help of government-industry partnerships that are the cornerstone of the PVMaT Project.

\section{CONCLUSIONS}

The PVMaT Project is currently completing its subcontracted efforts under the 3-yr solicitation, Phase 2A, with research in Phases $2 B$ and $3 A$ well under way. Proposals for product-driven research under the newest procurement, Phase 4A, are currently in the evaluation stage with awards expected later in 1995.

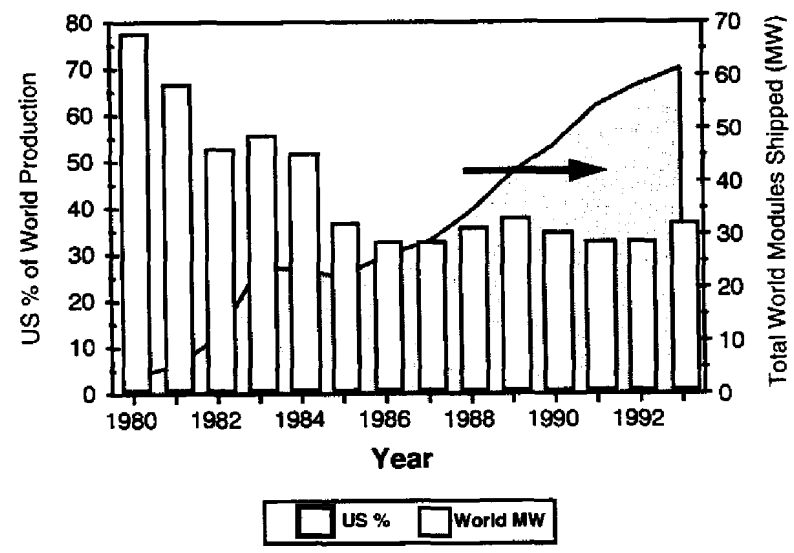

Fig. 5. US World and Module Shipments

The members of the U.S. PV manufacturing industry that have been participating in the DOE PVMaT government/industry R\&D partnership have made progress toward achieving their individual goals. They have been successful in increasing the performance and reliability of their products, increasing the yield and throughput of the production lines, reducing PV product manufacturing costs, introducing new product lines, and scaling-up PV manufacturing plant capacity. It is believed that these activities, supported by the PVMaT government/industry R\&D partnership, have had an effect on the strength and stability of the U.S. PV manufacturing industry as a whole, and this partnership is providing the U.S. industry with a solid base for a significantly improved and less costly renewable energy technology.

\section{ACKNOWLEDGEMENTS}

This work is supported under DOE contract DE-AC36$83 \mathrm{CH} 10093$ with NREL.

\section{REFERENCES}

[1] Witt, C.E.; Mitchell, R.; Mooney, G. D.; Herwig, L.O.; Hasti, D.; and Sellers, R. "Progress in Phases 2 and 3 of the Photovoltaic Manufacturing Technology Project (PVMaT)." Proceedings of the 23rd IEEE Photovoltaics Specialists Conference, Louisville, Kentucky, May, 1993, pp. 1228-1231.

Witt, C.B.; Herwig, L.P.; Mitchell, R.; and Money, G. D. "Status of the Photovoltaic Manufacturing Technology (PVMaT) Project." Proceedings of the 22nd IEEE Photovoltaics Specialists Conference, Las Vegas, Nevada, October, 1991, pp. 501-505.

Data for this figure were developed from the following sources:

PV Insiders Report, Vol. XIII, No. 2, 1994, p. 1.

PV News, Vol. 3, No. 2, 1984, p. 2.

PV News, Vol. 13, No. 2, 1994, p. 2.

Solar Energy Intelligence Report, Set. 9, 1986, p. 81.

Urja, The World PV Market, July 1985, p. 50.

Solar Collector Manufacturing Activity, 1993, DOE/E1AV0174 (93), Aug 1993, p. 19. 